\title{
Antibacterial activity testing of ethanolic extract of aloe vera leaf and gel against methicillin-resistant Staphylococcus aureus
}

\author{
Tias Eka Pratiwi*, Warta Dewi*, Eddy Prijono* \\ *Department of Oral Biology Faculty of Dentistry Universitas Padjadjaran
}

\begin{abstract}
Introduction: The interest on Aloe vera based herbal products is fast growing during recent years, particularly in medication regarding their antibacterial properties which had a lot of active components such as saponin and anthraquinone. Methicillin-resistant Staphylococcus aureus has emerged as one of the most important human pathogens causing nosocomial infections and became the first priority as a consequence of their resistancy. The purpose of this study is to determine the minimum levels of ethanol extract of leaves and Aloe Vera gel that can inhibit MRSA and find out whether there are differences in antibacterial power between of ethanol extract of leaves and Aloe Vera gel. Methods: Ten isolates of MRSA were investigated for their sensitivity to Aloe vera leaf and gel extract using the serial dilution method by doing two times repetition and statistically analyzed according to t-test method. Result: The result shows that the Minimum Inhibitory Concentration of Aloe vera leaf and gel extract each located at a concentration of $25 \%$ and $12,5 \%$. There is a significant difference in antibacterial power between the ethanol extract of leaves and Aloe Vera gel in inhibiting MRSA with MIC values of $25 \%$ and $12.5 \%$ Conclusion: There was a difference between Aloe vera leaf and gel extract antibacterial activity, where the gel extract is more effective than leaf extract.
\end{abstract}

Keywords: Aloe vera ethanolic extract leaf, Aloe vera ethanolic extract gel, MRSA, antibacterial activity

\section{INTRODUCTION}

Staphylococcus aureus is the leading cause of most bacterial infections that are toxic to humans, and this bacterium is found in many parts skin and nasopharynx where it can cause local infections of the skin, nose, urethra, vagina and gastro-ducts intestinal. ${ }^{1}$

Efforts to overcome Staphylococcus aureus infection initially was by using penicillin group antibiotics. Still, there was a change in the pattern the sensitivity of this bacterium to penicillin, so methicillin antibiotic was developed. ${ }^{2}$ Methicillin is known to inhibit the growth of Staphylococcus aureus. Still, after two years of usage, these bacteria become resistant to methicillin socalled methicillin-resistant Staphylococcus aureus (MRSA).

MRSA was first identified in a hospital. ${ }^{3}$ Research in the United States has managed to classify MRSA into two types, including hospitalacquired MRSA (HA-MRSA) which have proven to be resistant to many antibiotics and communityassociated MRSA (CA-MRSA) which have proven to 
be resistant only to class antibiotics B-lactam. ${ }^{4}$ In 2006 the prevalence of infection methicillinresistant Staphylococcus aureus in Indonesia reached $23.5 \%{ }^{5}$

World Health Organization (WHO) recommends the use of herbal ingredients as an alternative treatment to prevent bacterial resistance to certain types of antibiotics. One of the herbal ingredients that have been widely used to treat diseases is Aloe Vera.

Aloe Vera contains 75 ingredients that have benefits in the medical field, including lignin, saponin, and anthraquinone. Lignin is a cellulose substance found in Aloe Vera gel and can penetrate human skin. Saponin has been widely used as a detergent and contains antiseptic ingredients. Anthraquinone is located in the sap of Aloe Vera, and this ingredient can function as a painkiller and has antibacterial, antifungal, and antiviral abilities. Another component that is no less important in Aloe Vera is plant sterols. Sterols are anti-inflammatory, antiseptic, and analgesic. ${ }^{6}$

The results of the study stated that the antibacterial activity of Aloe Vera leaf extract with Aloe vera gel against Staphylococcus aureus at a concentration of $25 \mathrm{mg} / \mathrm{ml}$ resulted in inhibition zones of $18.0 \mathrm{~mm}$ each for gel extracts and $4.0 \mathrm{~mm}$ for leaf extracts. ${ }^{7}$ Similar things also occur in some gram-bacteria other positives, such as Streptococcus mutans which were successfully inhibited at a concentration of $12.5 \mu \mathrm{g} / \mathrm{ml}$ with an inhibition zone of $10 \mathrm{~mm}$ with ethanol gel extract, ${ }^{8}$ whereas Bacillus subtilis and Bacillus cereus with inhibition zones were $28 \mathrm{~mm}$ and 26.7 mm respectively. ${ }^{9}$

The purpose of this study is to determine the minimum levels of ethanol extract of leaves and Aloe Vera gel that can inhibit MRSA and find out whether there are differences in antibacterial power of of ethanol extract of leaves and Aloe Vera gel.

\section{METHODS}

This research is an experimental laboratory study. The population in this study is the Aloe Vera plantation found in Sekeloa and Dago areas, Bandung City. The study was conducted in May 2012 using the serial dilution method and statistically analyzed using the t-test method.
The variables in this study are Methicillinresistant Staphylococcus aureus, and ethanol extract of leaves and Aloe vera gels are divided into individual levels. The tools and materials used in this study are others, methylated lamps, sliding tubes, tweezers, pipettes, test tubes and racks, and other devices commonly used in the Microbiology Laboratory.

Making Aloe Vera leaf extract and Aloe vera gel was carried out at the Unpad Chemistry Laboratory. The initial step is to smooth the simplicia leaves and Aloe vera gel which has dried as much as 600 and 800 grams respectively then macerated using $70 \%$ ethanol so that all the simplicia powder is submerged by ethanol in the macerator. Maceration was carried out for $2 \times 24$ hours and every 24 hours, and the macerated were collected and remaserated with a new $70 \%$ ethanol solution. The macerate obtained is concentrated with a rotary evaporator until a thicker extract is obtained. The extract is then poured into a vaporizer cup, then evaporated on a water bath until an extract is obtained thick. Thick extract later is weighed. To achieve $100 \%$ concentration, weigh 100 grams of extract then add $100 \mathrm{ml}$ of distilled water.

The ethanol extract of the leaf and Aloe Vera gel was diluted to obtain a solution with a concentration of $50,37.5,25$, and $12.5 \%$ with the series dilution method. Provide six sterile test tubes, each numbered 1-6. The first tube was filled with $1 \mathrm{ml}$ of glucose bulb, then from a standard solution of ethanol extract of Aloe vera leaves pipetted as much as $1 \mathrm{ml}$, then stirred evenly to get a concentration of $50 \%$. The second tube was filled with $1.25 \mathrm{ml}$ of glucose bulb, then from a standard solution of ethanol extract of Aloe vera leaves pipette as much as $0.75 \mathrm{ml}$, then stirred evenly to get a concentration of $37.5 \%$. The third tube was filled with $1.5 \mathrm{ml}$ of glucose bulb, then from a standard solution of ethanol extract of Aloe vera leaves pipette $0.5 \mathrm{ml}$, then stirred evenly to get a concentration of $25 \%$. The fourth tube was filled with $1.75 \mathrm{ml}$ of glucose bulb, then from a standard solution of ethanol extract of Aloe vera leaves pipette as much as $0.25 \mathrm{ml}$, then stirred evenly to get a concentration of $12.5 \%$. The MRSA suspension in the ball that was made is equivalent to the turbidity of Mc. Farland 0.5 pipelines of 0.1 $\mathrm{ml}$ each into tubes 1 to 4 . Next, the entire tube 
incubated using the applicator at $370 \mathrm{C}$ for 24 hours. The tube as a control for bacterial growth was also incubated as the fifth tube containing only a bacterial suspension (control + ), and the tube as a sterility control material was incubated as the sixth tube containing only the test material (control -).

Observe the presence or absence of microbial growth by comparing positive controls. Minimum inhibitory levels are obtained to observe a tube that does not show bacterial growth at the lowest concentration. Tubes that display evident cultures indicate that the test material can inhibit the growth of microorganisms. Conversely, mixed cultures show the growth of test microorganisms because the test material is not able to hinder it.

Furthermore, as much as one solution from each tube was taken and then planted in
$\mathrm{LAB}$ and re-incubated using an excavator at $370 \mathrm{C}$ for 24 hours to confirm the previous results. That treatment the same is also applied using ethanol extract Aloe vera gel. MIC is indicated by concentration the smallest that can inhibit the growth of microorganisms. Each sample was tested twice with the same method.

\section{RESULTS}

The MIC test of ethanol extract of leaves and Aloe vera gel against MRSA isolates gave results as seen in table 1 .

Based on calculations, the Aloe Vera gel extract concentration of $50 \%$ there is no bacterial growth. Still, at concentrations of 37.5, 25, and $12.5 \%$, there began to be bacterial growth with

Table 1. Shows the results of sectoral tests to determine minimum concentration inhibition

\begin{tabular}{|c|c|c|c|c|c|c|c|c|c|c|c|}
\hline \multirow{2}{*}{ Sample } & \multirow{2}{*}{ Repeatation } & Gel & Gel & gel & Gel & Leaf & Leaf & Leaf & Leaf & Control & Control \\
\hline & & 50 & 37,5 & 25 & 12,5 & 50 & 37,5 & 25 & 12,5 & $(+)$ & $(-)$ \\
\hline \multirow[t]{2}{*}{1} & 1 & 0 & 0 & 0 & 89 & 0 & 0 & 336 & 525 & 934 & 0 \\
\hline & II & 0 & 0 & 0 & 66 & 0 & 0 & 320 & 390 & & \\
\hline \multirow[t]{2}{*}{2} & I & 0 & 0 & 0 & 4 & 0 & 0 & 41 & 628 & & \\
\hline & II & 0 & 0 & 0 & 3 & 0 & 0 & 20 & 134 & & \\
\hline \multirow[t]{2}{*}{3} & I & 0 & 2 & 328 & 0 & 0 & 0 & 76 & 668 & & \\
\hline & II & 0 & 1 & 449 & 1 & 7 & 1 & 102 & 355 & & \\
\hline \multirow[t]{2}{*}{4} & I & 0 & 0 & 0 & 10 & 1 & 3 & 294 & 176 & & \\
\hline & II & 0 & 0 & 1 & 4 & 1 & 0 & 272 & 69 & & \\
\hline \multirow[t]{2}{*}{5} & I & 0 & 0 & 1 & 0 & 1 & 1 & 37 & 94 & & \\
\hline & ॥ & 0 & 0 & 0 & 2 & 0 & 0 & 13 & 62 & & \\
\hline \multirow[t]{2}{*}{6} & I & 0 & 0 & 116 & 1 & 0 & 1 & 60 & 736 & & \\
\hline & II & 0 & 0 & 5 & 1 & 0 & 0 & 88 & 69 & & \\
\hline \multirow[t]{2}{*}{7} & I & 0 & 0 & 1 & 0 & 0 & 0 & 214 & 307 & & \\
\hline & II & 0 & 0 & 0 & 1 & 0 & 0 & 288 & 250 & & \\
\hline \multirow[t]{2}{*}{8} & I & 0 & 0 & 0 & 12 & 0 & 0 & 5 & 90 & & \\
\hline & II & 0 & 0 & 0 & 9 & 0 & 0 & 8 & 63 & & \\
\hline \multirow[t]{2}{*}{9} & I & 0 & 0 & 1 & 0 & 22 & 36 & 42 & 353 & & \\
\hline & II & 0 & 0 & 0 & 2 & 21 & 22 & 13 & 423 & & \\
\hline \multirow[t]{2}{*}{10} & I & 0 & 0 & 0 & 1 & 1 & 2 & 49 & 600 & & \\
\hline & II & 0 & 0 & 0 & 1 & 1 & 0 & 43 & 594 & & \\
\hline Rata-rata & & 0 & 0.15 & 45.1 & 10.35 & 2.75 & 3.3 & 116.05 & 329.3 & 934 & 0 \\
\hline
\end{tabular}

Table 2. Shows that the average MRSA growth in gel extracts with a concentration of $12.5 \%$ lower from leaf extract with a concentration of $25 \%$.

\begin{tabular}{ccccc|c|c|c}
\hline Sample & $\mathrm{N}$ & Mean & Std. Deviation & $\mathrm{T}$ & \multicolumn{1}{c}{ Df } & \multicolumn{1}{c}{ Sig. } & Kesimpulan \\
\hline Gel 12.5\% & 10 & 10.350 & 23.830 & -2.690 & 18 & 0.015 & MRSA dengan metode difusi agar \\
Daun 25\% & 10 & 116.050 & 121.958 & & & & Berbeda \\
\hline \hline
\end{tabular}


an average number of bacterial colonies of 0.15 , 45.1, and 10.35, respectively. The researchers determined that the minimum inhibitory concentration of Aloe vera gel extract, which could still inhibit MRSA colony growth was at a concentration of $12.5 \%$. In contrast to gel extracts, Aloe Vera leaf extract test results have begun to show bacterial growth at concentrations of 50 and $37.5 \%$. More and more colonies are growing at levels of 25 and $12.5 \%$ with each average number of bacterial colonies 2.75, 3.3, 116.05, and 329.3. The researcher determined that the minimum inhibitory concentration of Aloe Vera leaf extract, which could still inhibit MRSA colony growth was at a level of $25 \%$.

Table 2 shows that the average MRSA growth in gel extracts with a concentration of $12.5 \%$ lower from leaf extract with a concentration of $25 \%$. The test results are independent t-test can be concluded that the significance value of 0.015 is smaller than the p-value (sig.) of 0.05 , meaning that Aloe Vera gel extract $12.5 \%$ has a significant difference with leaf ethanol extract $25 \%$ in inhibiting the growth of MRSA.

\section{DISCUSSION}

Antibacterial power test of ethanol extract Aloe vera leaves and gels with concentrations of $50,37.5,25$, and $12.5 \%$ of MRSA in this study were carried out using the broth dilution method or series dilution. The advantage of this method is that the results obtained are qualitative in the form of Minimum Inhibitory Concentration (MIC), but the weakness of this method is that it requires a lot of material and specialised training in making serial dilutions so that the possibility of errors can be avoided. ${ }^{10}$

The results of the preliminary study were in the form of antibacterial effectiveness test of Aloe Vera leaf extract and gel against(wells) prove that Aloe Vera. The amount of extract concentration is proportional inversely with the number of growth bacteria. Test with this method is required as a preliminary test, so you can know whether the bacteria is still classified sensitive or resistant to test material. If the bacteria are still classified as sensitive, then proceed with serial dilutions to obtain the MIC material of the test material against bacteria.
Testing KHM gel extracts and Aloe Vera leaves as seen from the results of the planting sector (table 1) gives the result that there are differences extract concentration which can inhibit MRSA growth. Following Lethal Dose 50 (LD50), the concentration of ethanol extract of leaves and gels that showed the most minimal MRSA growth was $25 \%$ and $12.5 \%$, because at that concentration $50 \%$ of the total bacterial colonies could be inhibited. This is in line with research conducted by Agarry et al. (2005) which concluded that the ethanol extract of leaves and Aloe vera gel against Staphylococcus aureus was effective at a concentration of $25 \%$ with ethanol gel extract more effective than leaves. ${ }^{7}$

Based on the results of statistical calculations with the t-test method in table 2 , it can be seen that there is a significant difference between the ethanol gel extract of $12.5 \%$ and the aloe vera leaf extract $25 \%$ in inhibiting the growth of MRSA when viewed from the MIC value owned, with an average MRSA growth in gel extract with a concentration of $12.5 \%$ is lower than leaf extract with concentration of $25 \%$. This proves that ethanol gel extract is still more effective in inhibiting MRSA growth when compared to leaf extract.

Differences in MICs obtained between ethanol extracts of leaves and gels may occur due to differences in active substances contained in each part of the Aloe Vera. Based on phytochemical tests, Park and $\mathrm{Jo}^{11}$ state that Aloe vera has more than 75 nutrients and 200 active substances, including vitamins, enzymes, minerals, sugars, lignin, anthraquinone, saponins, salicylic acids, and amino acids. This active ingredient causes Aloe Vera to have an analgesic effect, and the wound heals antifungal and antibacterial. ${ }^{11}$

The most active substance found in leaves is an anthraquinone. Pellizoni et al. ${ }^{12}$ state that this substance has antibacterial power by inactivating the work of enzymes needed by bacteria. ${ }^{12}$ Enzymes play a role in the process of protein synthesis in the metabolic process. If the enzyme is inactivated, it will disrupt the metabolic process causing bacterial death. Another way of working with anthraquinone is to produce Reactive Oxygen Species (ROS), such as oxygen molecules. MRSA is known to live in Susana anaerobic facultative, which requires only a little 
air. Therefore anthraquinone works in a way increase oxygen levels so that bacterial growth can be inhibited. ${ }^{13}$

Aloe vera gel is also known contains various active substances, including saponin, acemannan, aloin and aloe-emodin. ${ }^{8}$ Saponin can cause saponification reactions and will cause damage to the bacterial membrane fat structure so that the bacterial cell wall will rupture and lysis and then die. ${ }^{14}$ Aloin and aloe-emodin are derivatives the main anthraquinone which has a polyphenol structure and can inhibit protein synthesis from bacterial cells disrupt metabolic processes. ${ }^{8}$

Acemannan is the most active complex carbohydrate compound, composed of glucose and manosa chains. ${ }^{12}$ this substance is thought to have an indirect antibacterial effect as an activating agent of the human immune system, related with its ability to increase the number of monocytes in the tissue and stimulate macrophages causing phagocytosis. ${ }^{15}$

The content of other active substances such as vitamins, enzymes, minerals, salicylic acid and amino acids, can interact with active antibacterial compounds that have been mentioned earlier and might influence the effectiveness of antibacterial in inhibiting the growth of MRSA.

The results of this study prove that the ethanol extract of leaves and Aloe Vera gel in vitro has been shown to have inhibitory properties against MRSA. The properties possessed by the two extracts in vitro are proven to have antibacterial power so it can be recommended to be used as alternative medicine in handling infections caused by MRSA after going through clinical trials. Further research is fundamental to do considering the many benefits of the Aloe Vera plant so that it can be used as an alternative treatment in the medical world to prevent further bacterial resistance.

\section{CONCLUSION}

There was a difference between Aloe vera leaf and gel extract antibacterial activity, where the gel extract is more effective than leaf extract.

\section{REFERENCES}

1. Harris LG, Foster SJ, Richards RG. An introduction to Staphylococcus aureus and techniques for identifying and quantifying S. aureus adhesins in relation to adhesion to biomaterial. Eur Cell Mater. 2002 Dec 31;4:3960.

2. Jawetz, Melnick P, Adelberg H. Medical Microbiology $24^{\text {th }}$ ed. New York: The McGraw Hill, Inc. 2007. p. 228.

3. Kurlenda J, Grinholc M, Jasek K, Wegrzyn, G. RAPD typing of methicillin-resistant Staphylococcus aureus: A 7-year experience in a polish hospital. Med Sci Monit 2007;13: MT13-8.

4. Reinberg S. 1.2 million U.S. patients get resistant staph each year. Available from: http: //medicinet.com/news_and_views / article.htm [Cited Nov 2011].

5. Andra. MRSA Update: Diagnosis dan Tatalaksana. Available from: http://www. majalah-farmacia.com/rubrik/one_news. asp?ID News=557 [Cited Nov 2011].

6. Atherton P. The essential Aloe vera. Newport Pagnell: Mill Enterprises 2007;41:49-54.

7. Olaleye MT, Bello-Michael CO. Comparative antimicrobial activities of Aloe vera gel and leaf. Afric J Biotech 2005;4(12):1413-14.

8. Fani M, Kohanteb J. Inhibitory activity of Aloe vera gel on some clinically isolated cariogenic and periodontopathic bacteria. J Oral Sci. 2012 Mar;54(1):15-21.

9. Shahzad K, Ahmad R, Nawaz S, Saeed S, Iqbal Z. Comparative antimicrobial activity of Aloe vera gel on microorganisms of public health significance. Pharmacologyonline 2009;1:41623.

10. Jorgensen JH, Ferraro MJ. Antimicrobial susceptibility testing: A review of general principles and contemporary practices. Clin Infect Dis. 2009 Dec 1;49(11):1749-55

11. Park YI, Jo TH. Perspective of industrial application of Aloe vera. New York Springer Verlag 2006. p.191-200.

12. Pellizzoni M, Ruzicknova G, Kalhotka L, Lucini L. Antimicrobial activity of different Aloe barbadensis Mill. and Aloe arborescens Mill. leaf fractions. J Medic Plants Res 2012;6(10):1975-81.

13. Montoya SC, Comini LR, Cabrera JL. Antimicrobial activity of natural 
photosensitizing anthraquinones. Formatex. 2011:3-13.

14. Francis G, Kerem Z, Makkar HPS, Becker K. The biological action of saponins in animal system. British J Nutrit 2002;88:587-605.
15. Womble D, Helderman JH. Enhancement of allo-responsiveness of human lymphocytes by acemannan. Int J Immunopharmacol. 1988;10(8):967-74. 